\title{
BIOLOGICAL DETERMINANTS OF PLANT AND CROP PRODUCTIVITY OF FLAX (Linum usitatissimum L.)
}

\author{
Tadeusz Zając, Andrzej Oleksy, Agnieszka Klimek-Kopyra, Bogdan Kulig
}

\author{
The Hugo Kołłątaj University of Agriculture in Kraków, Institute of Crop Production \\ al. A. Mickiewicza 21, 31-120 Kraków, Poland \\ e-mail: rroleksy@cyf-kr.edu.pl
}

Received: 27.04 .2012

\begin{abstract}
In Poland the cultivation of the fibrous form of flax ( $\mathrm{Li}$ num usitatissimum L.) is dying out, but the acreage of its oilseed form, linseed, which provides seed (Semen lini) used in therapy and being a source of -linolenic acid, is expanding. Nowadays, linseed is grown in 64 countries of the world, but yield levels in these countries vary greatly. Under European conditions, seed yield of linseed shows high variation, which is evidence of little knowledge of the biology of this plant and the lack of precise cultivation solutions in agricultural technologies used. A major reason is the difficulty in obtaining optimal crop density. A sparse crop results in low above-ground biomass yield, which is translated into insufficient crop yields. The selection of highly productive domestic and foreign varieties can partially increase linseed yield; apart from some domestic varieties, the Canadian cultivar 'Flanders' and the Hungarian cultivar 'Barbara' are positive examples in this respect. There is a possibility of effective selection at early stages of linseed breeding, which bodes well for the prospect of obtaining highly productive varieties with normal or very low -linolenic acid content.
\end{abstract}

Key words: flax, origin, acreage, growth, biomass yield, cultivars, yield structure

\section{INTRODUCTION}

The forms of flax (Linum usitatissimum L.) distinguished based on systematics and use, that is, fibre flax, intermediate flax, and linseed, have different morphological and qualitative traits as well as different agronomic and climatic requirements. For these reasons, the cultivation of flax for fibre, growing both the fibrous and intermediate form of flax due to very good adaptation of these two types of flax to the colder conditions of the temperate climate, had a major importance in our country from the most ancient times until the end of the $19^{\text {th }}$ century. In the past, growing fibrous or intermediate flax and processing flax straw for fibre were common. Obtained as by-product yield, flaxseed provided oil after pressing, which was originally used in whole for consumption purposes, but later also in industry. Moreover, seeds of all commercially used forms of flax are not laden with any narcotic compounds, therefore they have long been a safe food product, unlike seeds of cannabis - a fibrous plant of similar use.

In the 1990's, in most European countries an attempt was undertaken to restore the cultivation of linseed, treating it as an alternative agricultural crop. This effort was driven by the desire to gain a deeper knowledge of non-health-related properties of seed and oil (S i mopoulos, 1999). The results of agricultural research have made it evident that the level of linseed yield in European countries is low and very variable from year to year, but the causal factors are difficult to define unambiguously (B ravi and S o m movigo, 1997; C a s a et al. 1999; Di e pe n brock, 2001).

Given the significant decrease in fibre flax acreage after 2000, in Poland there is now a need replace its cultivation with linseed, since in this way linseed seed and oil as well as press cakes and extracted meal can be obtained, and not only through import. The impetus for these efforts is the unique composition of linseed oil and its seed. Compared to other oilseed plants, linseed seed is the most effective and stable source of n-3 -linolenic acid ( $\mathrm{Z}$ a j ą $\mathrm{c}$ et al. 2010).

Due to the beneficial health-promoting properties of linseed seed and oil, in particular ethyl esters of this oil, there is now a need to analyse and verify the obtained research results ( $\mathrm{R} \mathrm{e} \mathrm{g} \mathrm{u} \mathrm{ia}-\mathrm{S}$ a rd at et al. 2008). Such efforts will undoubtedly allow us to get 
to know better and understand the agrotechnology of linseed and will enable the development of the fundamentals of agrotechnology, whose implementation is necessary due to the need to maintain this agricultural crop in cultivation. The growing use of various flax-based products will become a stimulus for the expansion of linseed area harvested.

\section{THE ORIGIN AND CULTIVATED FORMS OF FLAX}

The genus Linum $\mathrm{L}$. is a member of the family Linaceae and this taxon includes more than 200 species found across the globe (H o n e r m e i er, 2006). Flax (Linum usitatissimum L.), also known as common or cultivated flax, is a diploid $(2 \mathrm{n}=30)$ and, at the same time, the only species of the family Linaceae which is of agricultural importance ( $\mathrm{He} \mathrm{y} \mathrm{w} \mathrm{o-}$ o d, 1978, cited after G ü r b ü z, 1999). The generic name Linum, known to the Greeks and Romans, comes from the Celtic word lin - thread (R u m iń s k a, 1990). The other word usitatissimum in the species name, given by Carl Linnaeus, means very useful, which directly refers to its multiple applications and their importance. This taxon is a collective species which includes the dehiscent flax group. $\mathrm{H}$ an elt (2001) divided flax Linum usitatissimum ssp. usitatissimum into several groups of botanical varieties, among which three varieties, notably convar. crepitans, usitatissimum, and mediterraneum, are still of major importance in cultivation. Convar. crepitans is dehiscent flax, an old and primitive spring form, with a barely 40-day growing period and whose capsules dehisce after ripening. This taxon can now be found in the mountainous regions of Portugal and Spain as well of Austria and Russia - as a relict cultivated plant, but it is slowly disappearing, since it produces oil and fibre of low quality. Convar. usitatissimum is fibre flax with a long stem and closed capsules. It has high water requirements and develops well in the colder regions of temperate climate, but nowadays, apart from Europe, it is also encountered in Asia, both Americas, and Australia. N ow ińs ki (1970) stresses that the old civilisations greatly appreciated this botanical variety as a provider of fibre necessary for making fabrics and clothes, whereas seed oil production was of lesser importance to them. The large-seeded flax forms with a short stem, which develop best in a warm and dry climate and which provide seeds and oil, are derived from convar. mediterraneum, hence they should be considered to be the protoplast of linseed.

The seed of cultivated forms of flax, called flaxseed (Semen lini), has long been used as a therapeutic agent, especially useful in treatment of digestive tract diseases, since it exhibits dietetic, purgative, and protective effects (R u mińska, 1990). Hanelt (2001) thinks that the oldest form of flax use was the consumption of whole seeds, or they may have been crushed or ground before their consumption, and then seeds in this form were added to dough from which bread was baked, e.g. in Ethiopia. W a kj i r a et al. (2004) report that in Ethiopia linseed has been grown since the ancient times and currently this country has one of the larger acreages of this type of flax at the global level (Table 1). Under the warmer temperate climate conditions, linseed occurs as a winter plant. In the Mediterranean Sea basin, local cultivars have long been grown, mainly facultative varieties of linseed, that is, varieties that can produce seed yield irrespective of the time of sowing - in autumn or in spring (D'A A tu on o and Ros sin i, 2006). Intermediate flax, combining the properties of fibre flax and linseed, was also cultivated in the past on the Polish soil, in Silesia and Lower Lusatia, in parallel to fibre flax (Lityński and Moldenhawer, 1971). It was likewise in the Podhale region where both flax forms were grown simultaneously (L i p i ń s k a , 1968).

Zohary (1999) as well as Lityńska- Zając and Wasylikowa (2005) are of opinion that all forms of cultivated flax originate from the wild narrow-leaved flax $L$. angustifolium (Huds.) Tell. (syn. L. bienne Mill.), since they have the same number of chromosomes $(2 n=30)$ and can be crossed with each other, as a result of which fertile hybrids are produced being valuable recombinants which increase the variation in species traits and, more importantly, in commercial traits. The domestication of the narrow-leaved flax took place in several centres across the world, though at different times. The transformation of the wild narrow-leaved flax into a cultivated species, common flax, was possible thanks to a systematic and long-lasting selection that had been going on since the Neolithic Age, as a result of which the spontaneous dehiscence of capsules was eliminated and the weight of seeds was increased by increasing their size - which are commercially important traits for linseed. Due to the selection taking place with fibre flax, the stem length was increased and this enabled an increase in the number of fibre bundles in a single stem (Lityńska-Zają c and W a sylikowa, 2005).

In addition to common flax, biennial flax (L. bienne Mill.), Linum humile Mill., and perennial flax (L. perenne L.) are also derived from the wild narrow-leaved flax. Linum perenne is a perennial found on limestone rocks of mountains and foothills. In these habitats, it forms clumps of plants which produce stems $60-100 \mathrm{~cm}$ high with light blue flowers that bloom in June and July. Today, the low habitat requirements of this species are appreciated; coupled with covering the soil with vegetation all year round, this 
provides good protection of the soil plough layer against sheet erosion in the undulating areas of Germany (W e i k et al. 2002). Purging flax (Linum catharticum L.), also called fair flax, grows in the wild in Poland (R u mi ń s k a, 1990).

In the past, Austrian flax (Linum austraicum L.) was grown in Poland and in the whole of Central Europe; in Poland this taxon is only found in warm and well-insolated sites. Nowadays, it is encountered only in the area of Przemyśl. It is a thermophilous, slow growth perennial and therefore both in lowland and upland it blooms at the height of the summer, thus 1-2 months later compared to common flax. This species is less productive and hence more primitive; that is why its cultivation was abandoned in the past and replaced with common flax, known already in Biskupin (W o y ke and $\mathrm{Mu}$ śnicki, 2003).

Harlan (1971) emphasises that flax was grown earliest in the Near East, which took place around $7300 \mathrm{BC}$, whence it came to Greece together with other domesticated plant species, probably 8000 years ago. Flax, together with the oldest species, among others, emmer wheat Triticum turgidum L. ssp. dicoccum Schüb. and einkorn wheat T. monococcum L., initiated the development of agriculture and, at the same time, of the ancient civilisations in the Fertile Crescent area (Zoh a ry, 1999). Around 6600 BC, the peoples of the Linear Pottery culture transferred the knowledge of flax cultivation and use from the Near East region to the area of central Europe, including the area of today's Poland.

\section{FLAX ACREAGE}

Table 1 shows the crop area of the leading commercial forms of flax - linseed and fibre flax, at the global level in the first decade of the 21st century, including seed yield per hectare and total production. The source of this statistical information is FAOSTAT (2011) which records flax cultivation in 64 countries. Durrant (1976), cited after Zają c et al. (2010), showed that linseed, in spite of the fact that it belongs to very old cultivated plants, was grown only in slightly more than 30 countries of Asia, Europe, America, and Africa (in the Ethiopian centre) at the turn of the 60 's and 70's of the 20th century. Linseed, which occupied an area of 2112 thousand hectares in 2009, is now predominant in cultivation in the world. Nevertheless, there is a noticeable tendency towards a reduction in harvested area of linseed which in several co- untries - Canada, India, Ethiopia, and the USA - is the only form of this species that is grown. Although seed yield per unit area is low, yet it shows an increasing trend, which allows one to expect that this commercial form of flax will maintain its place among agricultural crops. In the global scale, linseed competes for its place in agricultural space with soybean, as a major oilseed crop, while in Europe also with oilseed rape. As a result of the low level of linseed yield, similarly as in the case of field pea, a progressive marginalization of these species can be observed in cultivation in favour of soybean (world) and oilseed rape (Europe) as the leading oilseed crops which provide the largest amounts of plant protein in extracted meal for livestock (K li mek and Z a ją c, 2009). This adverse trend, on the one hand, reduces biodiversity in agriculture, and on the other hand, it introduces the cultivation of GMO varieties of soybean and oilseed rape. In the last reporting period - 2009, Canada had the highest share in the production of linseed seed across the world $43.8 \%$, followed by China $-15.0 \%$, India $-7.95 \%$, USA $-8.89 \%$, and Ethiopia $-7.10 \%$, whereas Europe accounts for $12.1 \%$ of this production. Ethiopia's linseed acreage has increased significantly as a result of broad-based research on local varieties and ecotypes, which have been confronted, in terms of their productivity and seed oil content, with the leading varieties supplied from Canada and the USA, the countries being the scientific and financial partners for this project (W a k j i r a et al. 2004). In these both countries from the North-American agricultural district of the world, seed yield of linseed is systematically growing, thereby the total share of these two countries in global linseed production exceeds $50 \%$, thus making them leading exporters of this agricultural produce. In $\mathrm{Ca}$ nada, linseed ranks sixth in importance among agricultural crops (J o hnston et al. 2002). A quicker decline in fibre flax acreage is observed than in the case of linseed, which can be partially attributed to the presently increasing acreage of GMO varieties of cotton. The noticeable decrease in fibre flax cultivation in favour of cotton over the centuries has probably resulted from the lack of bodies of water in the arid areas of the subtropical zone. It is known that flax straw processing requires large amounts of water necessary in both dew and water retting of flax straw, and water is usually in short supply in such areas, therefore the mankind has done the right thing in choosing cotton as the primary source of fibre and replacing flax with this species. 
Table 1

Comparison of trends in crop area as well as in yield and production of linseed seed and flax straw (fibre flax) in the world and in five leading countries

[FAOSTAT 2011]

\begin{tabular}{|c|c|c|c|c|c|c|c|c|c|}
\hline \multirow{2}{*}{ Specification } & \multirow{2}{*}{ Year } & \multicolumn{2}{|c|}{ Acreage ' 000 ha } & \multicolumn{2}{|c|}{ Percentage of acreage $\%$} & \multicolumn{2}{|c|}{ Yield q ha ${ }^{-1}$} & \multicolumn{2}{|c|}{ Production kt } \\
\hline & & linseed & flax & linseed & flax & linseed seed & flax straw & linseed & flax \\
\hline \multirow{3}{*}{ World } & 2009 & 2112 & 322 & 100 & 100 & 10.1 & 14.2 & 2124 & 458 \\
\hline & 2005 & 2785 & 495 & 100 & 100 & 9.8 & 19.9 & 2734 & 986 \\
\hline & 2000 & 2630 & 451 & 100 & 100 & 7.7 & 11.1 & 2012 & 499 \\
\hline \multirow{3}{*}{ China } & 2009 & 337 & 91 & 16.0 & 28.3 & 9.4 & 27.0 & 318 & 245 \\
\hline & 2005 & 490 & 159 & 17.6 & 32.1 & 9.7 & 43.7 & 475 & 695 \\
\hline & 2000 & 498 & 97 & 18.9 & 21.5 & 6.9 & 22.1 & 344 & 215 \\
\hline \multirow{3}{*}{ Canada } & 2009 & 623 & - & 29.5 & - & 14.9 & - & 930 & - \\
\hline & 2005 & 733 & - & 26.3 & - & 13.5 & - & 991 & - \\
\hline & 2000 & 591 & - & 22.5 & - & 11.7 & - & 693 & - \\
\hline \multirow{3}{*}{ India } & 2009 & 470 & - & 22.3 & - & 3.6 & - & 169 & - \\
\hline & 2005 & 449 & - & 16.1 & - & 3.8 & - & 170 & - \\
\hline & 2000 & 593 & - & 22.5 & - & 4.1 & - & 241 & - \\
\hline \multirow{3}{*}{ Ethiopia } & 2009 & 141 & - & 6.7 & - & 10.7 & - & 151 & - \\
\hline & 2005 & 215 & - & 7.7 & - & 5.9 & - & 126 & - \\
\hline & 2000 & 74 & - & 2.8 & - & 4.3 & - & 32 & - \\
\hline \multirow{3}{*}{ USA } & 2009 & 127 & - & 6.0 & - & 14.8 & - & 189 & - \\
\hline & 2005 & 386 & - & 13.9 & - & 12.9 & - & 500 & - \\
\hline & 2000 & 209 & - & 7.9 & - & 13.0 & - & 273 & - \\
\hline
\end{tabular}

Faostat: Date of access 14 November 2011.

In Europe, the area occupied by linseed has been decreasing faster than at the global level (Table 2). It can be assumed that the causal agent was the expansion of the cultivation of winter oilseed rape as a species that is currently the most effective for agriculture in terms of production. However, in animal feeding it is strongly recommended to use press cakes and extracted meal as well as ground seeds of oilseed plants, mainly oilseed rape and flax, liquid fish, and plant oils in order to increase in animal products the content of necessary unsaturated fatty acids (UFA) which guarantee a reduced cholesterol content in meat, milk, and egg yolks (Ć w i e k, 2006). Some parts of linseed seeds left after oil pressing are used for the production of milk substitutes for calves, which clearly shows the multiple and diverse applications of flax-based products.

High linseed yield of $1.99 \mathrm{t} \times \mathrm{ha}^{-1}$ (data for 2009) is obtained in the United Kingdom. However, large year-to-year variation in acreage is observed in this country, which proves the significant effects of business cycle factors (Table 2). In the United Kingdom and Ireland, intermediate flax is still grown both for textile purpose - the production of fibre used for making textiles and paper - and for seed used to extract linseed oil (Foster et al. 1998; A p pel, 1991). The above-mentioned authors stress that this double-purpose cultivation is more stable economically compared to the typical production of fibre flax (flax straw + seed as by-product yield), which is very sensitive to business cycle changes. In terms of linseed production in Europe, the countries specified in Table 2 had a total share of $81.1 \%$. Currently, Germany is missing from the group of European countries with developed flax cultivation, though quite recently Diepenbrock (2001) suggested that linseed should be considered to be the third ranking oilseed crop in terms of economic importance, alongside oilseed rape and sunflower. 
Table 2

Crop area as well as yield and production of linseed seed and fibre flax in six leading European countries [FAOSTAT, 2011]

\begin{tabular}{|c|c|c|c|c|c|c|c|c|c|}
\hline \multirow{2}{*}{ Specification } & \multirow{2}{*}{ Year } & \multicolumn{2}{|c|}{ Acreage '000 ha } & \multicolumn{2}{|c|}{ Percentage of acreage $\%$} & \multicolumn{2}{|c|}{ Yield $\mathrm{q} \mathrm{ha}^{-1}$} & \multicolumn{2}{|c|}{ Production kt } \\
\hline & & linseed & flax & linseed & flax & linseed seed & flax straw & linseed & flax \\
\hline \multirow{3}{*}{ Europe } & 2009 & 279.4 & 216.5 & 100 & 100 & 9.20 & 9.24 & 257.1 & 200.1 \\
\hline & 2005 & 366.8 & 319.4 & 100 & 100 & 9.30 & 8.65 & 341.2 & 276.1 \\
\hline & 2000 & 504.1 & 333.4 & 100 & 100 & 6.02 & 8.01 & 303.6 & 267.0 \\
\hline \multirow{3}{*}{ Russian Federation } & 2009 & 80.7 & 63.6 & 28.9 & 29.4 & 12.72 & 8.26 & 102.6 & 52.6 \\
\hline & 2005 & 61.4 & 89.2 & 16.7 & 27.9 & 9.10 & 6.26 & 55.9 & 55.9 \\
\hline & 2000 & 87.6 & 92.7 & 17.4 & 27.8 & 5.84 & 5.50 & 51.2 & 51.0 \\
\hline \multirow{3}{*}{ France } & 2009 & 56.2 & 56.6 & 20.1 & 26.1 & 3.67 & 11.84 & 20.6 & 67.0 \\
\hline & 2005 & 78.6 & 78.6 & 21.4 & 24.6 & 7.53 & 12.21 & 59.2 & 96.0 \\
\hline & 2000 & 54.5 & 62.9 & 10.8 & 18.9 & 6.82 & 11.92 & 37.2 & 75.0 \\
\hline \multirow{3}{*}{ Belarus } & 2009 & 48.1 & 64.8 & 17.2 & 29.9 & 2.09 & 7.24 & 10.0 & 46.9 \\
\hline & 2005 & 72.1 & 72.1 & 19.7 & 22.6 & 2.70 & 6.99 & 19.5 & 50.4 \\
\hline & 2000 & 82.0 & 82.0 & 16.3 & 24.6 & 2.02 & 4.54 & 16.6 & 37.2 \\
\hline \multirow{3}{*}{ Ukraine } & 2009 & 18.0 & 1.8 & 6.4 & 0.8 & 6.67 & 6.67 & 12.0 & 1.2 \\
\hline & 2005 & 25.0 & 23.6 & 6.8 & 7.4 & 11.28 & 5.38 & 28.2 & 12.7 \\
\hline & 2000 & 20.0 & 19.8 & 4.0 & 5.9 & 2.50 & 4.19 & 5.0 & 8.3 \\
\hline \multirow{3}{*}{ United Kingdom } & 2009 & 29.0 & 10.2 & 10.4 & 4.7 & 19.91 & 14.46 & 56.0 & 14.7 \\
\hline & 2005 & 48.0 & 11.5 & 13.1 & 3.6 & 18.54 & 14.22 & 89.0 & 16.4 \\
\hline & 2000 & 74.0 & 18.0 & 14.7 & 5.4 & 5.81 & 15.56 & 43.0 & 28.0 \\
\hline \multirow{3}{*}{ Belgium } & 2009 & 11.2 & 11.3 & 4.0 & 5.2 & 6.59 & 11.08 & 7.4 & 12.5 \\
\hline & 2005 & 19.3 & 19.0 & 5.3 & 5.9 & 5.32 & 9.72 & 10.3 & 18.5 \\
\hline & 2000 & 13.7 & 13.6 & 2.7 & 4.1 & 10.80 & 11.95 & 14.8 & 16.2 \\
\hline \multirow{3}{*}{ Poland } & 2009 & 1.6 & 1.9 & 0.6 & 0.9 & 12.82 & 2.22 & 2.1 & 0.4 \\
\hline & 2005 & 1.0 & 6.0 & 0.3 & 1.9 & 16.58 & 3.30 & 1.7 & 2.0 \\
\hline & 2000 & 0.5 & 4.1 & 0.1 & 1.2 & 9.74 & 19.27 & 0.5 & 7.9 \\
\hline
\end{tabular}

Faostat: Date of access 14 November 2011.

\section{YIELD OF FLAX VARIETIES}

During the ontogenetic development of linseed plants, seed yield components develop in the fixed, biologically determined order, that is, in the following order: the number of plants (stems) per $1 \mathrm{~m}^{2}$, then the number of capsules per plant (stem), and subsequently the number of seeds per capsule, whereas at the final stage of the growing season (maturation stage) 1000 seed weight is determined ( $\check{\mathrm{C}} \mathrm{andrakova}$ and $\mathrm{Baku}$ la, 2001; Zając and Oleksy, 2010). According to Č andrakova and Bakula (2001), for yield in the range of 4.5-5.0 $\mathrm{t} \times \mathrm{ha}^{-1}$ (a very high level, rather unattainable), the values of the successively developing linseed yield components should be as follows: number of stems per $1 \mathrm{~m}^{2} 600-700$; number of capsules per stem 15-22; number of seeds per capsule 8-9; 1000 seed weight (g) 5.5-6.0; above-ground biomass yield 9.0-10.0 t DW ha ${ }^{-1}$; and the harvest index $0.46-0.50$.
Under field conditions, plant density, followed by the number of seed capsules per stem and seed weight, have the largest contribution to the formation of yield components, whereas the number of seeds per capsule has a smaller effect on the amount of yield due to the genetic conditions of linseed. The ranges of linseed yield presented in Table 3 are similar to the results of experiments and agricultural practice in Poland and in the world (Tables 1 and 2). Wit k ow i c z et al. (2005) estimated that the proportion of the explained (regression) variation in linseed yield in the total variation was $68 \%$, out of which the individual effect of plant density was $24 \%$, while that of the number of capsules, number of seeds per capsule, and 1000 seed weight was, respectively: 15.0, 3,0 and 26\%. As determined by Zając et al. (2005), the harvest index for linseed primarily depends on the growing season and cultivar, and the range for this trait was from 0.31 to 0.51 , which means that growing season conditions strongly 
modify the mutual proportions of vegetative and generative parts. The distribution of accumulated dry matter among particular organs included in final yield affects the value of the harvest index (M a r s a ll et al. 1989; Cas a et al. 1999; A u fhammer et al. 2000). Above-ground dry matter yield, estimated for the successive plant growth stages, is an expression of potential productivity of a linseed crop (Fig. 1). In line with the expectations, the rate of increase in dry weight of linseed plants per 1 ha had the shape of an S-curve, and the same correlation direction was also described in an earlier paper ( $\mathrm{Z} \mathrm{a} \mathrm{j} \mathrm{ą} \mathrm{c} \mathrm{et} \mathrm{al.} \mathrm{2002).}$

Productivity of a linseed crop at characteristic growth stages can be presented by using many parame- ters, such as: CGR, NAR, RGR (B a z z a z and $\mathrm{H}$ a r per, 1977; Marshall et al. 1989; A u f ha m mer et al. 2000). Marshall et al. (1989) showed that the linseed cultivar 'Dufferin' was not stable in yield, since seed yield during the period 1985-87 was as follows: $87.2,132.7$, and $121.8 \mathrm{~g} \mathrm{~m}^{2}$, while the leaf area index $\left(\mathrm{m}^{2} \times \mathrm{m}^{-2}\right)$ was, respectively: 2.0, 6.0, and 1.2. Such data show that in the years with adverse weather conditions the linseed crop managed to produce satisfactory seed yield, even with the small area of leaf blades. The distribution of dry matter among above-ground plant parts can be inferred based on the value of LAR (B a z z a z and Harper, 1977; M a r s hall et al. 1989).

Table 3

Mean values and their ranges for particular linseed yield components with planned productivity $\left(\mathrm{t} \times \mathrm{ha}^{-1}\right)$ at a level of 2.0 or 1.5 tonnes (acc. to $\mathrm{Z} \mathrm{a} \mathrm{j} \mathrm{ą} \mathrm{c} \mathrm{and} \mathrm{O} \mathrm{le} \mathrm{k} \mathrm{s} \mathrm{y,} \mathrm{2010)}$

\begin{tabular}{lcccc}
\hline \multirow{2}{*}{ First-order components } & \multicolumn{2}{c}{2 tonnes per ha } & \multicolumn{2}{c}{1.5 tonnes per ha } \\
\cline { 2 - 5 } & Mean & Range from-to & Mean & Range from-to \\
\hline Number of plants per 1 m & 400 & $300-470$ & 300 & $250-350$ \\
Number of capsules per plant (pcs.) & 12 & $8-14$ & 13 & $8-16$ \\
Number of seeds per capsule (pcs.) & 8 & $7-9(10)$ & 8 & $7-9(10)$ \\
1000 seed weight (g) & 5.5 & $5-6.5$ & 5.5 & $5-6.0$ \\
Number of seeds per plant (pcs.) & 96 & $80-110$ & 96 & $75-125$ \\
Single plant yield (g) & 0.5 & $0.42-0.75$ & 0.5 & $0.45-0.60$ \\
\hline
\end{tabular}

Detailed investigations of the physiological indices characterizing the growth and development of plants in an oilseed crop most frequently relate to one cultivar and have usually been conducted under controlled conditions ( $\mathrm{H}$ a s s a n and Le it ch, 2000). Only A ufhammer et al. (2000) carried out a two-year study covering two cultivars under field conditions. The results of field and greenhouse experiments show that linseed yield is determined by the ability of plants and of the crop to accumulate dry matter throughout the whole ontogenesis (D i e p e n b r o ck et al. 1995; A u f h a m mer et al. 2000; Hassan and Leitch, 2000; $\mathrm{Z} \mathrm{a} \mathrm{j} \mathrm{ą} \mathrm{c} \mathrm{et} \mathrm{al.} \mathrm{2005).} \mathrm{A} \mathrm{comparative} \mathrm{analysis} \mathrm{of}$ the physiological indices in relation to three leading oilseed plant species, carried out by D i e p e n b r o c k (2001), showed that the amount of this information with regard to linseed is substantially smaller. Flax, irrespective of its cultivated form, produces many leaves on the stem, which hinders the estimation of the plant and crop leaf area. K u r t et al. (2006) report that the flax leaf area can be calculated based on the formula $\mathrm{LA}\left(\mathrm{cm}^{2}\right)=(0.5785+0.2612 \times \mathrm{LL}+1.5144 \times \mathrm{LW}+$ $0.14395 \times \mathrm{LL} \times \mathrm{LW}^{2} . \mathrm{R}^{2}=0.962(\mathrm{P}<0.01)$.

In many agricultural experiments on linseed, it has been demonstrated that dry matter accumulation by plants of this species very strongly depends on the climatic conditions during the growing season ( $\mathrm{M}$ a r shall et al. 1989; Diepenbrock et al. 1995; Ca s a et al. 1999; Froment et al. 2000; Has s a n and Leitch, 2000; Zając et al. 2002). Based on the results of field experiments, these authors stress that linseed yield in European countries is very variable (Die pen brock et al. 1995; Z u ba l, 2001; Strašil and Vorlíček, 2004; D'Antuono and Rossini 2006). Bravi and Sommovigo (1997) proved that linseed yield was affected to an above-average degree by the climatic conditions prevailing during two growth stages, that is, during the time of sowing and emergence as well as during the plant maturation stage.

$\mathrm{Zu} \mathrm{b}$ a 1 (2001) underlines that too low linseed stem density per unit area obtained under field conditions, which reflects to a small extent the actual amount of seeds sown, results in lower yields. It was probably due to this reason that under the conditions of Slovakia the linseed seeding rate of $6,8,10$, and 12 million germinating seeds was found not to have a significant effect on yield of two cultivars. This is evidence that habitat conditions strongly influence stem density in a given year and that the seeding rate has a small effect 
on the formation of crop density during harvest $(\mathrm{Zu}$ b a 1, 2001). A similar direction of correlation between seeding rate and linseed yield was obtained by D ' A n t u o n o and R o s s in i (2006) under the conditions of central Italy, while for Germany and Switzerland by Diepenbrock et al. (1995). Zają c (2005) found that the seeding rate of linseed influenced seed yield and its components. Sowing 600 seeds of linseed per $1 \mathrm{~m}^{2}$ produced the highest yield $-1.89 \mathrm{t}$ per ha. This yield was higher by $7.4 \%$ compared with the lower rate -300 seeds per $1 \mathrm{~m}^{2}$.

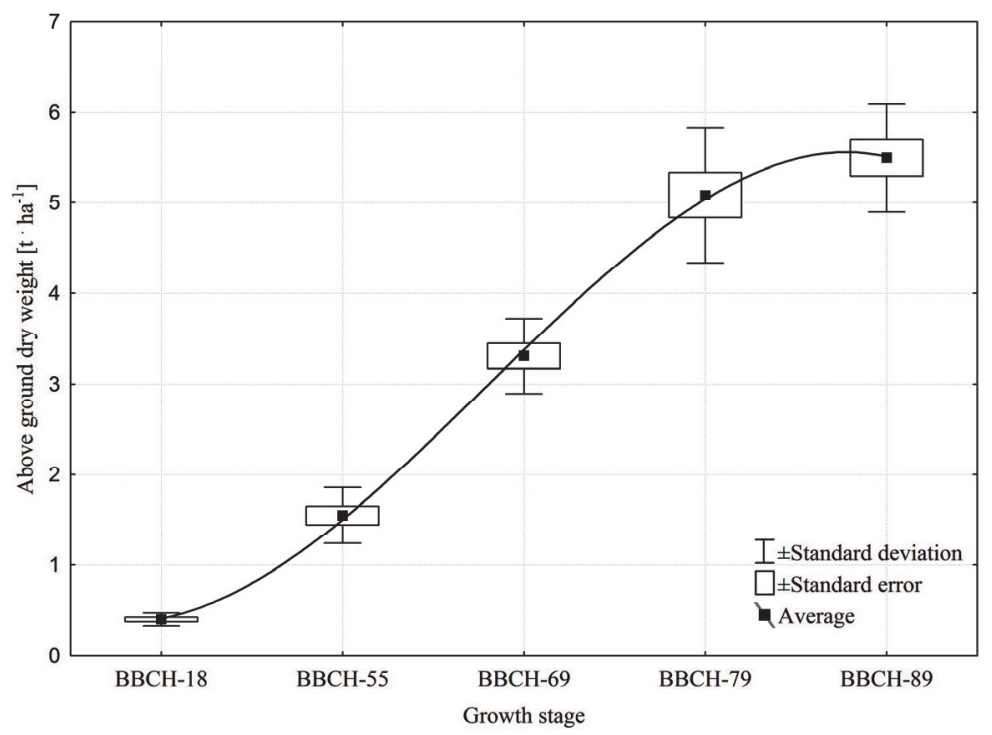

Fig. 1 Increase in above-ground dry weight of linseed at characteristic growth stages (acc. to Z a ją c et al. 2005).

Eas s on and Molloy (2000) evaluated the response of the cultivar 'Flanders' in the case of double-purpose cultivation, that is, for seed or for fibre, applying a seeding rate (the number of seeds per $1 \mathrm{~m}^{2}$ ) of 500 seeds in seed crops and a higher seeding rate of 1500 seeds in fibre crops, and they found that dense sowing increased raw fibre yield by $25 \%$ as a result of the increased technical length of stems. Seed yield obtained from a densely sown linseed crop increased insignificantly, since intraspecific competition in the excessively dense crop canopy caused a decline in seed yield components. This confirms the need to achieve optimal density in linseed crops grown for seed. A justified view, with a high degree of probability, can be formulated that too low density of linseed plants adversely affects seed yield obtained, despite that cultivars of this species, at low plant density, seek to compensate and increase stem density in the crop by the branching of plants at their base or by increasing panicle branching (H o c k in g, 1995; Z a j ą c, 2004).

Table 4

Effect of nitrogen rates on productivity of flax plants 'Linola ${ }^{\text {TM }}$ 947'

in relation to seed yield components and oil content (acc to. H o c k i n g, 1995)

\begin{tabular}{cccccccc}
\hline $\begin{array}{c}\text { N supply rates } \\
\left(\mathrm{mg} \mathrm{L}^{-1}\right)\end{array}$ & $\begin{array}{c}\text { Stem/root dry } \\
\text { weight ratio }\end{array}$ & $\begin{array}{c}\text { Number of capsules } \\
\text { per plant }^{-1}(\mathrm{pcs})\end{array}$ & $\begin{array}{c}\text { Number of seeds } \\
\text { per capsule }{ }^{-1}(\mathrm{pcs} .)\end{array}$ & $\begin{array}{c}1000 \text { seed } \\
\text { weight }(\mathrm{g})\end{array}$ & $\begin{array}{c}\text { Seed yield per } \\
\text { plant }^{-1}(\mathrm{~g})\end{array}$ & $\begin{array}{c}\text { Seed oil } \\
\text { content }^{(\%)}\end{array}$ & $\begin{array}{c}\text { Oil yield per } \\
\text { plant }\end{array}$ \\
\hline 14 & 3.1 & $53(32)^{*}$ & 6.6 & 6.32 & 2.24 & 40.9 & 0.91 \\
35 & 5.3 & $125(51)$ & 6.1 & 7.08 & 5.40 & 41.4 & 2.24 \\
70 & 7.1 & $194(51)$ & 6.4 & 6.76 & 8.35 & 40.9 & 3.42 \\
140 & 7.7 & $215(56)$ & 6.0 & 6.68 & 8.71 & 41.3 & 3.60 \\
210 & 8.3 & $224(59)$ & 5.9 & 6.44 & 8.52 & 41.0 & 3.40 \\
350 & 8.3 & $195(70)$ & 4.2 & 5.63 & 4.59 & 38.4 & 1.76 \\
700 & 12.5 & $173(72)$ & 4.4 & 5.08 & 3.90 & 38.1 & 1.49 \\
LSD $_{(\mathrm{P}=0.05)}$ & - & 32 & 0.6 & 0.31 & 0.88 & 1.5 & 0.37 \\
\hline
\end{tabular}

* - The percentage (\%) of lateral branch capsules is given in parentheses. 
Table 4 presents the process of branching of linseed plants 'Linola ${ }^{\mathrm{TM}}$ ' 947 ' as a response to increasing nitrogen rates in a pot experiment ( $\mathrm{H} \mathrm{o} \mathrm{c} \mathrm{k} \mathrm{i} \mathrm{n} \mathrm{g,}$ 1995). This author showed that increasing nitrogen rates $\left(\mathrm{mg} \times \mathrm{dm}^{-3}\right): 14,35,70,140,210,350,700$, stimulated the formation of lateral branches by plants; this process started relatively late, since it took place from day 44 until day 72 , counting from the date of sowing. Medium nitrogen rates gave at least a $50 \%$ proportion of lateral branch capsules in the total amount of fruit per plant. Increased nitrogen fertilization changed the ratio between above-ground and underground parts of linseed plants. High nitrogen rates reduced the number of seeds per capsules, including a reduction in their weight as well as a decrease in oil content and oil yield, hence one cannot recommend such a level of fertilization under field conditions due to increased plant lodging, and this form of damage leads directly to reduced yields and hinders harvesting of seed from linseed plants.

Zajac (2004) established that under field conditions the intensity of branching in plants of linseed varieties with different seed colours primarily depends on the initial density of young plants and, to some extent, also on weather conditions directly after sowing, in April and May. In years with weather conditions favourable for linseed growth, from 23 to $40 \%$ of plants in a crop branched out, which was translated into a measurable production effect. The biosocial position of a shoot in the plant determined the dimensions of the structural traits. The dominance of the main stem over lateral branches was noticeable, and it was evident in particular in relation to the number of capsules developed. Among the main factors limiting good yield of linseed grown for seed, B r a m m and Dambroth (1992) include the nitrogen rate; in their opinion, the rate of not less than $60 \mathrm{~kg} \mathrm{~N} \times$ $\mathrm{ha}^{-1}$ gives the possibility of obtaining a density of 450 plants (stems) per $1 \mathrm{~m}^{2}$, which creates the prospect of satisfactory yields.

Canadian linseed varieties, in particular the brown-seeded ones, are considered to be particularly well adapted to temperate climate conditions, since they are marked by higher vigour than the yellow-seeded varieties (S a e idi and R ow land, 1999). $\mathrm{Zaj}$ ą c et al. (2005) demonstrated that, among linseed cultivars, the Canadian cultivar 'Flanders' and the Hungarian cultivar 'Barbara' were characterized by stable and high yields in Poland in all study years. 'AC Linora' was also distinguished by high yield, except for the year 2001 in which a reduction in its productivity occurred which is difficult to explain. The only domestic cultivar 'Opal' produced yield at a significantly lower level compared to other cultivars, which is a reason justifying the cultivation of foreign linseed cultivars in our country ( $\mathrm{Z} \mathrm{a} \mathrm{j}$ ą $\mathrm{c}$ et al. 2005).

\section{TRENDS IN BREEDING NEW CULTIVARS}

Dribnenki et al. (1999) presented the complicated, in breeding terms, origin of $\mathrm{cv}$. 'Linola ${ }^{\mathrm{TM}}$ '1084', which is a result of crossbreeding between the cultivar 'Flanders' and the line 'FP 946' characterized by low -linolenic acid content. The line 'FP 946' was obtained by crossbreeding four breeding lines: McGregor/Zero//CPI84495/3/McGregor. The fact should be stressed that the line 'Zero' with low -linolenic acid content was obtained from the Australian cultivar 'Glenelg' after treating its seeds with mutagenic factors. The most important commercial traits of all linseed cultivars of the Linola ${ }^{\mathrm{TM}}$ family are presented in Table 5. These linseed cultivars belong to the Solin type, therefore they are characterized by yellow seed colour and reduced -linolenic acid content, up to $2 \%$ in total acid content. Measurable outputs of this qualitative breeding of linseed include seven cultivars that have an increasingly shorter growing period and a decreasing height of the stem, which improves the harvest index. In the successive cultivars from this family, protein content increased more strongly, while oil content increased to a lesser degree, which proves a constant improvement of the qualitative characters resulting from the ongoing breeding programme. Oil from Linola ${ }^{\mathrm{TM}}$ linseed cultivars was to be used for margarine production, replacing sunflower oil in this process, but due to a change in the fatty acid profile it lost its nutritional properties. It should be stressed in particular that linseed oil (except for that obtained from the Solin type) contains two polyunsaturated long-chain fatty acids, that is, -linolenic acid ( -LNA) and linoleic acid (LA), which have the character of vitamin F. Since these acids are not synthesised in the tissues of mammals, they must be therefore supplied to humans in diet. 
Table 5

Comparison of yield, agricultural and commercial traits, oil and protein content in seeds of Linola ${ }^{\mathrm{TM}}$ cultivars belonging to linseed of the Solin type (acc. to Dribnenki and Green, 1995; Dribnenki et al. 1999)

\begin{tabular}{|c|c|c|c|c|c|c|c|c|c|}
\hline \multirow[t]{2}{*}{ Cultivar } & \multirow[t]{2}{*}{$\begin{array}{c}\text { Year of } \\
\text { breeding }\end{array}$} & \multicolumn{2}{|c|}{$\begin{array}{l}\text { Seed yield depend- } \\
\text { ing on soil colour } \\
\left(\mathrm{kg} \times \mathrm{ha}^{-1}\right)\end{array}$} & \multirow{2}{*}{$\begin{array}{c}\text { Growing season } \\
\text { duration-sowing } \\
\text { to harvest } \\
\text { (days) }\end{array}$} & \multirow{2}{*}{$\begin{array}{c}\text { Plant } \\
\text { height at } \\
\text { harvest } \\
(\mathrm{cm})\end{array}$} & \multirow{2}{*}{$\begin{array}{c}1000 \\
\text { seed } \\
\text { weight } \\
(\mathrm{g})\end{array}$} & \multirow{2}{*}{$\begin{array}{c}\text { Seed } \\
\text { oil con- } \\
\text { tent } \\
\left(\mathrm{g} \times \mathrm{kg}^{-1}\right) \\
\end{array}$} & \multirow{2}{*}{$\begin{array}{l}\text { Percentage of } \\
\text {-linolenic acid } \\
\text { in fatty acid } \\
\text { profile }(\%)\end{array}$} & \multirow{2}{*}{$\begin{array}{l}\text { Protein con- } \\
\text { tent in defatted } \\
\text { seeds } \\
\left({\left.\mathrm{g} \times \mathrm{kg}^{-1}\right)}\right.\end{array}$} \\
\hline & & black & brown & & & & & & \\
\hline '947' & 1995 & 2000 & 1940 & 103 & 64 & 5.3 & 442 & 2.0 & 368 \\
\hline ‘989’ & 1996 & 2030 & 2000 & 99 & 65 & 5.4 & 422 & 2.0 & 373 \\
\hline '1084' & 1999 & 2060 & 2080 & 101 & 65 & 5.3 & 454 & 1.8 & 367 \\
\hline '1084' & 1999 & 1520 & 1590 & 97 & 53.7 & 5.3 & 459 & 1.9 & 457 \\
\hline '2047' & 2003 & 1540 & 1470 & 97.5 & 51.9 & 5.5 & 474 & 2.0 & 504 \\
\hline '2090' & 2004 & 1570 & 1650 & 97 & 49 & 5.8 & 474 & 1.7 & 472 \\
\hline '2126' & 2005 & 1610 & 1580 & 96 & 48 & 5.5 & 472 & 1.4 & 492 \\
\hline
\end{tabular}

In Hungary linseed breeding programmes were started in 1929. During the last 20 years, 13 cultivars have been registered (A n o $\mathrm{i} \mathrm{m}, 1999)$. The breeding of the cultivar 'Szegedi 62' in 1981, which produced seed yields at the highest world level, was a breakthrough in the Hungarian linseed breeding programme. The next cultivar 'Sandra' was registered in Hungary in 1987; it was characterized by a short growing season and developed short stems, which produced short straw resistant to lodging; at the same time, it was the first Hungarian patented cultivar. After its registration, the proportion of this cultivar in the linseed crop structure in Hungary was $80 \%$. The next Hungarian cultivar was 'Barbara', registered in 1989, which likewise 'Sandra' was characterized by a short growing season and short straw, which probably led to its wide spread in different countries. This cultivar dominated in the United Kingdom both in terms of area occupied and seed yield $\left(4.4 \mathrm{tha}^{-1}\right)$. In a comparative study on productivity of cultivars in the United Kingdom, 'Barbara' became the only cultivar from outside Canada used as a standard to compare yields (S a e i d i and R ow l an d, 1999). Together with the Canadian cultivars 'McGregor', 'Flanders', and 'NorLin', it was a reference for productivity of British cultivars (F r o m e n t et al. 2000).

In the study on linseed breeding conducted by G ó $\mathrm{r}$ a l et al. (2006), it was demonstrated that 'Linola Tм 947' and 'Opal' were characterized by a significant, positive general combining ability for stem height and number of capsules per plant, which means the effectiveness of selection in early hybrid generations. In recombination breeding aimed at increasing seed yield, the cultivars 'Barbara' and 'Linola ${ }^{\mathrm{TM}}$ 947', characterized by the opposite sign of general combining ability for number of capsules per plant and 1000 seed weight as well as with positive effects as regards the number of capsules per plant, can be recommended (G ó r a 1 et al. 2006). In 2011 four linseed cultivars - two yellow-seeded ones: 'Jantarol' and 'Oliwin', as well as two brown-seeded ones: 'Szafir' and 'Bukoz', were registered in the national register of agricultural plant varieties.

\section{SUMMARY}

This paper presents the origin of commercial forms of flax and their contemporary importance for cultivation, taking into account yield levels obtained under experimental and agricultural practice conditions. Nowadays, an increased demand for flax-based products and food of high nutritional value is noticeable. Production of such food requires it to be enriched with linseed oil derivatives as a source of -linolenic acid. In the paper, changes in flax acreage are compared in the world (five countries) and in Europe (seven countries). Low flax yields, in the case of both commercial forms of flax - linseed and fibre flax, place this species in an unfavourable position in terms of production relative to major agricultural crops. The systematic decline in the acreage of flax at the global level and in Europe probably results from too low yields, from the point of view of farmers' expectations, from quickly increasing productivity of soybean (world) and oilseed rape (Europe) as well as from the competition of cotton as a source of fibre. Flax yield levels achieved in European countries are very variable from year to year, which is determined by low above-ground biomass yield and, as a consequence, low stem density in a crop; this in turn is influenced by agricultural technology and agroclimatic conditions of a given growing season. The selection of highly productive domestic and foreign varieties can partially increase linseed yield. Therefore, the research on potential productivity of new breeding lines will help choose those characterized by high yield levels; apart from new domestic varieties, the Canadian cultivar 'Flanders' and 
the Hungarian cultivar 'Barbara' are positive examples in this respect.

\section{Acknowledgements}

This research was carried out under the project N N310 151837

\section{REFERENCES}

A n o n i m. 1999. Linseed breeding. Gabonatermesztesi Kutato Kft.: 15-22.

A p pel R.S.W. 1991. The linseed market in the United Kingdom. Asp. Appl. Biol. No. 28: 1-6.

Aufhammer W., Wägner W., Kaul H.-P., Kübler E. 2000. Strahlungsnutzung durch Bestände ölreicher Körnerfruchtarten - Winterraps, Öllein und Sonnenblume im Vergleich. J. Agron. \& Crop Sci. 184: 277-286. http://dx.doi.org/10.1046\%2Fj.1439-037x.2000.00395.x

Bazzaz F. A., Harper J. L. 1977. Demographic analysis of the growth Linum usitatissimum. New Phytol. 78: 193-208. http://dx.doi.org/10.1111\%2Fj.1469-8137.1977. tb01558.x

B ram m A., Dambroth M. 1992. Influence of genotype, crop density and nitrogen fertilization on the yield capacity of linseed. Landbauforschung-Voelkenrode, 42(3): 193-198.

Bravi R., Sommovigo A. 1997. Seed production and certification of flax/linseed [Linum usitatissimum]. Sementi-Elette, 43(2): 5-8.

Čandrakova E., Bakula J. 2001. Vplyv hnojenia dusikom na morfologicke znaky, urodotvorne prvky a urody semena lanu siatego. Acta fytotech. zootech. 1: 9-12.

Casa R., Russell G., Lo Cascio B., Rossini F. 1999. Environmental effects on linseed (Linum usitatissimum L.) yield and growth of flax at different stand densities. Eur. J. Agron. 11: 267-278. http://dx.doi.org/ $10.1016 \% 2 F S 1161-0301 \% 2899 \% 2900037-4$

Ćwi ek A. 2006. Wpływ dodatków tłuszczowych w mieszankach treściwych na przemiany w żwaczu owiec. Mps. pracy doktorskiej. Bibl. Gł. UR w Krakowie: 1-139. (in Polish)

D'Antuono L. F., Rossini F. 2006. Field potential and ecophysiological traits of the Altamurano linseed (Linum usitatissimum L.), a landrace of southern Italy. Genetic Res. Crop Evol. 53: 65-75.

Diepenbrock W. 2001. Crop physiology of oilseeds: a comparative analysis between rapeseed (Brassica napus L.), sunflover (Helianthus annuus L.), and linseed (Linum usitatissimum L.). Sci. Agric. Bohemica, 32 (4): 323-339.

Diepenbrock W., Leon J., Clasen K. 1995. Yielding ability and yield stability of linseed in Central Europe. Agron. J. 87: 84-88. http://dx.doi.org/10.2134\%2 Fagronj1995.00021962008700010015x

Dribnenki J.C.P., Green A.G. 1995. Linola ${ }^{\mathrm{TM}}$ '947 low linolenic acid flax. Can. J. Plant Sci. 75: 201-202.
Dribnenki J.C.P., McEachern S.F., Green A.G., Kenaschuk E.O., Rashid K.Y. 1999. Linola TM '1084' low linolenic acid flax. Can. J. Plant Sci. 79: 607-609.

Easson D.L., Molloy R.M. 2000. A study of the plant, fibre and seed development in flax and linseed (Linum usitatissimum) grown at a range of seed rates. J. Agric. Sci. 135: 361-369. http://dx.doi.org/10. 1017\%2FS0021859699008400

Foster R., Pooni H.S., Mackay I.J. 1998. Quantitative analysis of Linum usitatissimum crosses for dualpurpose traits. J.. Agric. Sci. 131: 285-292. http://dx.doi. org/10.1017\%2FS0021859698005917

Froment M.A., Turley D., Collins L.V. 2000. Effect of nutrition on growth and oil quality in linseed. Tests of Agrochem. and Cult. 21: 29-30.

Góral H., Jasieński M., Zając T. 2006. Combining abilities of several of linseed with respect to yield components. Biul. IHAR. 240/241: 237-242. (in Polish)

Gürbüz B . 1999. Determination of cross - pollination in flax (Linum usitatissmum) using different experimental designs. J. Agric. Sci. 133: 31-35. http://dx.doi.org/ $10.1017 \% 2 F S 0021859699006723$

H a nelt P. (red.), 2001. Mansfeld's encyclopedia of agricultural and horticultural crops. 1-6. Springer, Berlin.

Harla n J. R. 1971. Agricultural origins: centers and noncenters. Science, 174: 468-474. http://dx.doi.org/10.1126\% 2Fscience.174.4008.468

H o cking. J. 1995. Effects of nitrogen supply on the growth, yield components and distribution of nitrogen in Linola. J. Plant Nutr. 18(2): 257-275. http://dx.doi.org/10. $1080 \% 2 \mathrm{~F} 01904169509364899$

Hon e r mei e r B . 2006. Öllein: 254-261. [In:] Ölfrüchte, Faserpflanzen, Arzneipflanzen und Sonderkulturen.(red. Heyland K.-U., Hanus H., Keller E. R.) Eugen Ulmer KG. (in German)

Johnston A.M., Tanaka D.L., Miller P.R., Brandt S.A., Nielsen D.C., Lafond G.P., Riveland N.R. 2002. Oilseed crops for semiarid cropping systems in the northern Great Plains. Agron. J. 94: 231-240. http://dx.doi.org/10.2134\%2Fagronj 2002. 0231

Klimek A., Zając T. 2009. Produkcyjność grochu (Pisum sativum L.) na tle postępu hodowlanego. / Productivity of pea (Pisum sativum L.) in view of the progress in plant breeding. Adv. Agric. Sci. 1: 77-91. (in Polish)

Kurt O., Uysai H., Uzun S. 2006. Allometric model for leaf area estimation linseed (Linum usitatissimum L.). Turk J. of Field Crops, 11: 1-5.

Li i ińska M. 1968. Badania nad miejscowymi odmianami lnu z rejonu Podhala. Mps pracy doktorskiej. Kraków: 1-39. (in Polish)

Lityńska-Zając M., Wasylikowa K. 2005. Len zwyczajny - Linum usitatissimum L., 127-129. [In:] Przewodnik do badań archeobotanicznych. Sorus, Poznań. (in Polish) 
Lityński A., Moldenhawer K. 1971. Rośliny oleiste: 153-230. [In:] Szczegółowa Hodowla Roślin (ed.) T. Ruebenbauer PWRiL Warszawa. (in Polish)

Marshall G., Morrison I.N., Nawolsky K. 1989. Studies on the physiology of (Linum usitatissimum L.): The application of mathematical growth analysis: 3947. [In:] Flax: Breeding and utilisation. Kluwer academic publishers Dordrecht.

Nowiński M. 1970. Dzieje upraw i roślin uprawnych. PWRiL Warszawa: 1-387. (in Polish)

Reguła-Sardat A., Zając T., Zagrodzki P. 2008. Produkty funkcjonalne - tak, ale jaki kierunek? Agrotrendy. 18(99), 32-33. (in Polish)

Ru miń ska A. 1990. Len zwyczajny: 263 i 279. [In:] Leksykon roślin leczniczych. (eds) A. Rumińska i A. Ożarowski PWRiL Warszawa. (in Polish)

Saeidi G., Rowland G.G. 1999. Seed colour and linolenic acid effects on agronomic traits in flax. Can. J. Plant Sci. 79: 521-526. http://dx.doi.org/10.4141\%2FP99-019

Sankari H.S. 2000. Linseed (Linum usitatissimum L.) cultivars and breeding lina as stem biomass producers J. Agron. \& Crop Sci. 184: 225-231.

Simopoulos A.P. 1999. Essential fatty acids in health and chronic disease. Amer. J. Clinic. Nutr. 70: 560-569. http://dx.doi.org/10.1080\%2F87559129709541143

Strašil Z., Vorlíček Z. 2004. Effect of soil and weather conditions and some agricurtural practices on yield and yield components in linseed (Linum usitatissimum L.). Sci. Agric. Bohemica, 35(2): 52-56.

Wakjira A., Labuschangne M.T., Hugo A. 2004. Variability in oil content and fatty acid composition of Ethiopian and introduced cultivars of linseed. J. Sci. Food Agric. 84: 601-607. http://dx.doi.org/10. $1002 \% 2$ Fjsfa. 1698

Weik L., Kaul H.-P., Kübler E., Aufhammer W. 2002. Grain yields of perennial grain crops in pure and mixed stands. J. Agron. \& Crop Sci. 188: 342-349. http://dx.doi.org/10.1046\%2Fj.1439-037X.2002.00580.x

Witkowicz R., Zając T., Kryńska B., Klima K. 2005. Variation and interrelation of yield components in linseed. Acta Agr. et Silv.ser. Agr. 45: 11-17. (in Polish)

Woyke T., Muśnicki Cz. 2003. Rośliny włókniste: 507-560. [In:] Szczegółowa Uprawa Roślin (eds) Z. Jasińska, A. Kotecki 2, AWA Wrocław. (in Polish)

$\mathrm{Zając} \mathrm{T.} \mathrm{2004.} \mathrm{Analiza} \mathrm{rozgałęziania} \mathrm{się} \mathrm{roślin} \mathrm{lnu} \mathrm{oleiste-}$ go (Linum ussititassimum L.) z uwzględnieniem wkładu tego procesu w zmienność i współzależność cech, / Analysis of linseed (Linum ussititassimum L.) plant branching as related to variability and interdependence of traits. Acta Agrobot. 57; (1-2): 187-205. (in Polish)

Zają c T. 2007. Uprawa rzepaku na biopaliwo: 7-108. [In:] Biopaliwo rzepakowe (eds) T. Juliszewski, T. Zając PWRiL oddział Poznań. (in Polish)

Zając T., Antonkiewicz J., Witkowicz R. 2002. Kształtowanie się zawartości wybranych pierwiastków w roślinach lnu oleistego (Linum usitatissimum L.) w za- leżności od fazy rozwojowej i części rośliny. / Selected element contents formation in linseed plants (Linum usitatissimum L.) depending on the phase of development and plant part. Acta Agrobot. 55 (2): 37-50. (in Polish)

Zając T., Grzesiak S., Kulig B., Polacek M. 2005. The estimation of productivity and yield of linseed (Linum ussititassimum L.) using the growth analysis. Acta Physiol. Plant. 27(4A): 549-558.

Zając T., Klima K., Borowiec F., Witkowicz R., Barteczko J. 2002. Yielding of linseed varieties in various site conditions. Rośliny Oleiste XXIII: 275-286. (in Polish)

Zając T., Oleksy A. 2010. Len oleisty: 125-140. [In:] Rośliny oleiste - uprawa i zastosowanie, (eds) W. Budzyński, T. Zając, PWRiL Oddział w Poznaniu. (in Polish)

Zając T., Oleksy A., Kulig B., Klimek A. 2010. Uwarunkowania plonowania formy oleistej lnu zwyczajnego (Linum usitatissimum L.) oraz jej znaczenie żywieniowe i lecznicze. / Determinants of linseed ( $\mathrm{Li}$ num usitatissimum L.) yield and its nutritional and medicinal importance. Acta Sci. Pol. Agric. 9(2): 47-63. (in Polish)

Zohary D. 1999. Monophyletic vs. polyphyletic origin of the crops on which agriculture was founded in the Near East. Genetic Res. Crop Evol. 46: 133-142.

Zubal P. 2001. Vplyv terminu sejby, vysevku a vyżivy na urodu lanu siateho olejneho (Linum usitatissimum L.). Ved. Prace Vys. Ust. Rastl. Vyr. Piestany, 30: 33-38. (in Slovak)

\section{Biologiczne determinanty produktywności roślin i lanu formy oleistej Inu zwyczajnego (Linum usitatissimum L.)}

\section{Streszczenie}

W Polsce powoli wygasa uprawa formy włóknistej lnu zwyczajnego (Linum usitatissimum L.), natomiast rozszerza się areał zasiewów formy oleistej, dostarczającej nasion (Semen lini), wykorzystywanych w lecznictwie i będących źródłem kwasu -linolenowego. Współcześnie len oleisty uprawiany jest w 64 krajach świata, w których poziom plonowania jest bardzo zróżnicowany. W warunkach europejskich wielkość plonu nasion lnu oleistego wykazuje dużą zmienność, co świadczy o małej znajomości biologii tej rośliny oraz braku precyzyjnych rozwiązań uprawowych w stosowanych agrotechnologiach. Zasadniczym powodem jest trudność w uzyskaniu optymalnej obsady roślin w łanie. Rzadki łan warunkuje niskie plony nadziemnej biomasy, co przekłada się na niezadowalające plonowanie. Dobór wysokoplennych krajowych i zagranicznych odmian może częściowo 
zwiększyć plonowanie lnu oleistego, a pozytywne przykłady w tym względzie stanowią poza odmianami krajowymi kanadyjska 'Flanders' oraz węgierska 'Barbara'. Istnieje możliwość skutecznej pracy selek- cyjnej we wczesnych etapach hodowli lnu oleistego, rokującej otrzymanie wysokoplennych odmian o normalnej lub bardzo niskiej zawartości -linolenowego. 